\title{
Ekosistem Pesantren dalam Mewujudkan Manajemen Halal Supply Chain Menuju Madani Society 5.0
}

\author{
Suwanto1), Indra Gunawan²) \\ 1), 2) Universitas Islam Negeri Sunan Kalijaga Yogyakarta, Indonesia ${ }^{1}$ \\ Corresponding author: suwantoawan@gmail.com
}

\begin{abstract}
Halal supply chain management is certainly very strategic applied in the halal industry in the environment around the islamic boarding school towards madani society 5.0. This study aims to describe the principles of halal supply chain management in islamic boarding school; analyze the islamic boarding school ecosystem in realizing halal supply chain management, and explain the challenges of implementing the islamic boarding school based halal supply chain management towards madani society 5.0. This study uses a qualitative descriptive method using a hermeneutic content analysis model and the integration-interconnection approach in detail the islamic boarding school ecosystem in order to develop halal supply chain management. In general, the four principles of the halal supply chain, namely halal procurement, halal manufacturing, halal distribution, and halal logistics. The islamic boarding school ecosystem in implementing halal supply chain management certainly requires government support, transportation planning, information technology management, human resource management; collaborative relations, halal certification, and traceability of halal information.
\end{abstract}

Keywords: islamic boarding school, management, halal supply chain, and madani society 5.0.

\begin{abstract}
Abstrak
Manajemen halal supply chain tentunya sangat strategis diterapkan pada industri halal di lingkungan sekitar pesantren menuju madani society 5.0. Penelitian ini bertujuan untuk menguraikan prinsip-prinsip manajemen halal supply chain pada pesantren; menganalisis ekosistem pesantren dalam mewujudkan manajemen halal supply chain; dan menjelaskan tantangan penerapan manajemen halal supply chain berbasis pesantren menuju madani society 5.0. Penelitian ini menggunakan metode deskriptif kualitatif dengan menggunakan model content analysis hermeneutik dan pendekatan integrasi-interkoneksi menganalisis secara rinci ekosistem pesantren dalam rangka mengembangkan manajemen halal supply chain. Secara umum empat prinsip halal supply chain, yaitu halal procurement (pengadaan), halal manufacturing (pengolahan), halal distribution (distribusi), dan halal logistic (rantai pasokan). Ekosistem pesantren dalam implementasi manajemen halal supply chain tentunya membutuhkan dukungan pemerintah, perencanaan transportasi, manajemen teknologi informasi, manajemen sumber daya manusia, hubungan kolaboratif, sertifikasi halal, dan ketelusuran informasi halal.
\end{abstract}

Kata kunci: pesantren, manajemen, halal suply chain, dan madani society 5.0. 


\section{PENDAHULUAN}

United Nations melaporkan bahwa bidang industri menjadi salah satu fokus dalam mewujudkan Sustainable Developmen Goals (SDGs) ${ }^{1}$. Adapun Industri halal (halal industry) menjadi bagian dari sektor yang dikembangkan negara-negara di dunia, termasuk Indonesia. Berdasarkan data PEW Research, populasi Muslim merupakan yang terbesar di dunia mencapai angka 1,7 miliar jiwa ${ }^{2}$. Indonesia sebagai negara dengan jumlah penduduk muslim terbesar di dunia, tentu membuat industri halal menjadi komoditas strategis serta peluang pertumbuhan ekonomi Indonesia kedepannya.

Peluang Indonesia menjadi pusat industri halal dunia juga semakin terbuka. Hal ini disebabkan karena selain populasi umat muslim terbesar, juga disebabkan berkembangnya berbagai sektor industri halal yang tersebar di wilayah Indonesia. Belum lagi, permintaan produk halal yang cukup tinggi. Peningkatan jumlah umat muslim ini tentunya berbanding lurus dengan banyaknya permintaan produk halal ${ }^{3}$. Apalagi, pengeluaran global konsumen muslim \$ 3,7 triliun pada 2019 di sektor makanan dan gaya hidup 4 .

Peningkatan populasi dan daya beli umat Islam mampu memperkuat trend gaya hidup halal. Gaya hidup halal dipandang sebagai pola hidup baru untuk penduduk muslim di dunia, tidak terkecuali Indonesia. Bahkan konsep halal sudah diterima oleh muslim maupun nonmuslim. Implikasi fenomena praktik halal di Indonesia saat ini tidak hanya pada sektor makanan dan minuman saja. Tetapi juga, sektor lain seperti pertanian dan peternakan. Selain itu, sebagaimana disebutkan Waharini \& Purwantini industri halal juga menyasar ke sektor keuangan, travel, pakaian, kosmetik, wisata, pendidikan, dan kesehatan ${ }^{5}$. Namun, dewasa ini penelitian dalam kajian ini masih terbatas 6 .

Sayangnya, berbagai persoalan berkaitan dengan industri tersebut masih terus terjadi. Kecurangan-kecurangan pada produk masih banyak ditemui di Indonesia. Misalnya saja, kasus penggantian secara sengaja bahan baku utama pada makanan yang diganti dengan daging babi. Selain itu, kurang kehati-hatian dalam menyiapkan bahan produksi. Belum lagi, masalah kecurangan terhadap produk label halal di dalam supply chain ${ }^{7}$.

Sejauh ini, berbagai potensi tersebut juga belumlah dimanfaatkan secara optimal. Hal ini karena kawasan industri halal masih terbilang langka dan jarang ditemui di Indonesia. Bahkan, Indonesia masih menempati urutan kesepuluh untuk kategori produsen makanan halal di dunia. Sebaliknya, justru menduduki peringkat pertama untuk konsumsi makanan halal ${ }^{8}$.

Indeks tersebut juga menunjukan bahwa Indonesia masih berada di bawah Malaysia dalam mengembangkan industri halal. Industri halal yang ada di Indonesia saat ini juga masih belum banyak yang dapat dipastikan proses persiapan dari hulu hingga hilir. Sistem rantai pasok di Indonesia masih belum sesuai standar dalam membangun kawasan industri halal.

\footnotetext{
${ }^{1}$ United Nations, “The Sustainable Development Goals Report”, (New, 2019).

2 Muhammad Djakfar, Pariwisata Halal Perspektif Multidimensi: Peta Jalan Menuju Pengembangan Akademik \& Industri Halal di Indonesia (Malang: UIN-Maliki Press, 2017).

${ }^{3}$ Mian N; Muhammad M. Chaudry Riaz, Halal Food Production (New York: CRC Press LLC, 2004).

${ }^{4}$ Hendri Hermawan Adinugraha and Mila Sartika, "Halal Lifestyle di Indonesia," An-Nisbah: Jurnal Ekonomi Syariah 5, no. 2 (2019): 57-81.

${ }^{5}$ Faqiatul Mariya Waharini and Anissa Hakim Purwantini, "Model Pengembangan Industri Halal Food di Indonesia," Jurnal Muqtasid 9, no. 1 (2018): 1-13.

${ }^{6}$ Nailil Muna \& Wahyudi Sutopo, "Perkembangan Penelitian Halal Food Supply Chai: Studi Kasus Database Scopus," in Prosiding SNST Ke-9 Tahun 2018 (Fakultas Teknik Universitas Wahid Hasyim, 2018), 131-39.

${ }^{7}$ Haryono Haryono and Dwi Iryaning Handayani, "Pemodelan Sistem Traceability Halal Supply Chain dalam Menjaga Integritas Produk Makanan Halal dengan Pendekatan Interpretive Structural Modeling (ISM)," Jurnal PROZIMA (Productivity, Optimization and Manufacturing System Engineering) 2, no. 2 (2018): 70-79.

${ }^{8}$ Thomson Reuters, "State of The Global Islamic Economy Report 2016-2017" (Dubai, 2016).
} 
Sementara itu, pesantren yang dikenal sebagai lembaga pendidikan tertua di Indonesia memiliki populasi terus meningkat seiring dengan berkembangnya zaman. Berdasarkan data Emis 2015/2016, jumlah pesantren yang besar tersebar di seluruh provinsi di Indonesia sebanyak 28.984, dengan jumlah santri sebanyak 4.290.6269. Seiring berkembangnya zaman pesantren banyak melakukan diversifikasi program dalam merespon perubahan. Diantaranya dengan menjalankan berbagai program pemberdayaan sosial ekonomi untuk menunjang kemandirian pesantren ${ }^{10}$.

Manajemen halal supply chain berbasis pesantren tentu sangatlah strategis. Apalagi, santri di pesantren sudah terbiasa menerapkan gaya hidup halal dan Islami. Pemilihan prioritas barang halal diterapkan santri karena memegang ajaran Islam. Selama ini, keberadaan pesantren mampu memberikan pembiasaan santri untuk menerapkan konsep halal di berbagai aspek kehidupan sehari-hari, seperti dalam pengelolaan keuangan dan pertimbangan halal dalam pembelanjaan barang dan jasa yang dibutuhkan ${ }^{11}$.

Berdasarkan berbagai persoalan tersebut perlu manajemen halal supply chain agar supaya berbagai potensi pesantren dapat dimanfaatkan secara optimal, sehingga dapat membantu memajukan ekonomi Indonesia. Perkembangan zaman yang memunculkan trend industri halal sudah semestinya dapat dimanfaatkan pesantren dan pemerintah dalam mengembangkan manajemen halal supply chain.

Oleh karenanya, berdasarkan paparan diatas perlu adanya eksplorasi mengenai prinsip-prinsip manajemen halal supply chain dalam ekosistem pesantren menuju Madani Society 5.0, ekosistem pesantren dalam mewujudkan manajemen halal supply chain menuju Madani Society 5.0, dan tantangan pesantren penerapan manajemen halal supply chain menuju Madani Society 5.0.

\section{METODE PENELITIAN}

Jenis penulisan karya tulis ini ialah eksploratif yang bersifat deskriptif-kualitatif dan bercorak pure research. Tujuannya ialah mengembangkan suatu disiplin ilmu (disiplinteoritik) dengan pendekatan integrasi-interkoneksi ilmu serta kajian implementasi berkaitan dengan manajemen halal suppy chain. Lebih jelasnya

Gambar 1.

Tahapan Penulisan

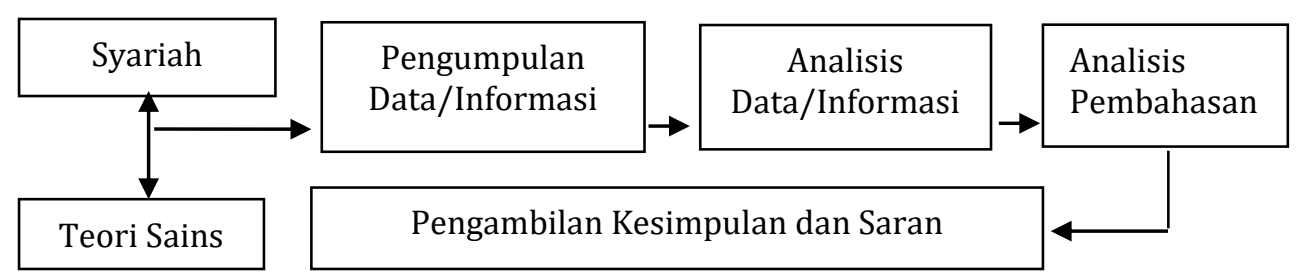

Fokus penelitian ini ialah mengintegrasikan-interkoneksikan Syariah dan sains manajemen, dalam rangka menganalisis manajemen halal supply chain di pesantren sebagai pemberdayaan ekonomi menuju Madani Society 5.0. Sumber data dalam penulisan ini berupa jurnal, buku, prosiding seminar, dan lainnya yang relevan dengan manajemen halal supply chain di pesantren. Teknik pengumpulan data memakai metode penulisan kepustakaan

\footnotetext{
${ }_{9}^{9}$ Achmad Muchaddam Fahhan, "Sanitasi dan Dampaknya Bagi Kesehatan: Studi Dari Pesantren," Jurnal Masalah-Masalah Sosial 10, no. 1 (2019): 33-47.

${ }^{10}$ Mohammad Nadzir, "Membangun Pemberdayaan Ekonomi di Pesantren," Economica: Jurnal Ekonomi Islam 6, no. 1 (2015): 37-56.

${ }^{11}$ Ning Purnama Sariati and Binti Mutafarida, "Pesantren dan Konsumsi Halal Santri (Studi Kasus di Pesantren Syarif Hidayatulah Rejomulyo Kediri)," vol. 2, 2019, 193-212.
} 
(library research) yang dikuatkan oleh kajian penelitian yang relevan. Analisis data dalam penelitian ini menggunakan model content analysis dan hermeneutik, yaitu suatu analisis tekstual dalam studi pustaka melalui investigasi terhadap isi dalam berbagai literatur dan penelitian relevan dengan pendekatan integrasi-interkoneksi ${ }^{12}$.

\section{HASIL DAN PEMBAHASAN}

\section{A. Prinsip-Prinsip Manajemen Halal Supply Chain}

Supply chain menjadi bagian penting dalam suatu industri ${ }^{13}$, termasuk pada industri halal. Adapun faktor-faktor halal supply chain meliputi aturan dan kebijakan halalan toyyiban; dukungan dari pemerintah dan swasta; halal hub; diferensiasi pemasok Muslim dan nonMuslim; kontrol dan pelabelan halal; kontrol logistik; kontrol kualitas; sumber daya; proses bisnis rantai pasokan halal; struktur jaringan pemasok; kinerja rantai pasokan halal; proses sertifikasi; dan sistem penelusuran halal ${ }^{14}$.

Semua produk halal harus mengikuti kaidah syariah, tidak terkecuali proses logistiknya. Oleh karena itu, perlu adanya proses logistik (supply chain) yang menerapkan prinsip-prinsip syariah dalam pelaksanaannya. Adapun prinsip utama halal supply chain yaitu memastikan pemisahan antara produk halal dan non-halal. Dari seluruh halal supply chain, pihak penyedia jasa layanan logistik berperan penting memastikan bahwa bahan mentah, bahan baku, pengemasan, penyimpanan, dan transportasi produk halal dilakukan secara benar serta tidak terkontaminasi produk non-halal15. Adapun, prinsip-prinsip halal supply chain digambarkan Gambar 4.1 berikut.

Gambar 2.

Prinsip Halal Supply Chain

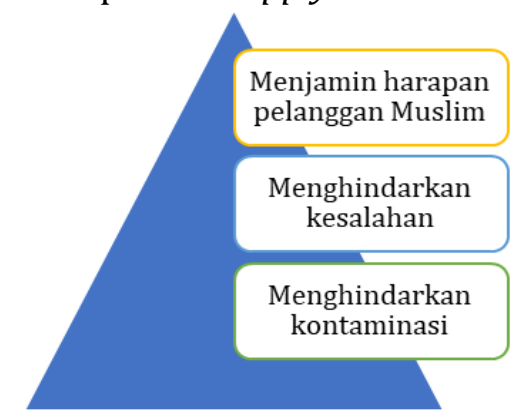

Sumber: Tieman, Vorst, dan Ghazali ${ }^{16}$

Salah satu sistem pengembangan industri halal yang efektif dan efisien yaitu manajemen halal supply chain. Sistem ini telah sukses diterapkan di Malaysia, sehingga industri halalnya optimal. Manajemen halal supply chain tentunya harus ditunjang

12 M. Amin Abdullah, Islamic Studies Di Perguruan Tinggi: Pendekatan Integratif-Interkonektif (Yogyakarta: Pustaka Pelajar, 2006): 107.

${ }^{13}$ Fernando C.A. Santos, "Integration of Human Resource Management and Competitive Priorities of Manufacturing Strategy," International Journal of Operations and Production Management 20, no. 5 (2000): 610-28.

${ }^{14}$ Adam Mohd Saifudin, Siti Norezam Othman, and Ezanee Mohamed Elias, "Exploring in Setting a Model for Islamic Supply Chain in Malaysia" 7, no. 1 (2017): 95-102.

${ }^{15}$ Jan Mei Soon, Mahmood Chandia, and Joe Mac Regenstein, "Halal Integrity in the Food Supply Chain," British Food Journal 119, no. 1 (2017): 39-51.

${ }^{16}$ M. Tieman; van der Vorst; M. Che Ghazali, "Principles in Halal Supply Chain Management," Journal of Islamic Marketing 3, no. 3 (2012): 217-43. 
manajemen pengetahuan atau knowledge management yang terintegrasi ${ }^{17}$ berorentasi pada pertumbuhan ${ }^{18}$, dan manajemen komunikasi yang baik ${ }^{19}$.

Secara sederhana manajemen halal supply chain didefinisikan sebagai rantai pasok produksi dengan sertifikasi halal dari bahan baku hingga produk yang siap dikonsumsi. Demikian juga tidak adanya kecacatan dalam prosesnya ${ }^{20}$. Untuk kesuksesan Manajemen Halal Supply Chain yang tepat karena sangat rentan dengan kondisi-kondisi eksternal21. Selain itu, dalam bekerja sama dengan pasar ${ }^{22}$ dan/atau bank harus terbebas dari gharar, tadlis, dan riba ${ }^{23}$.

Manajemen halal supply chain mengatur mulai dari penyedian bahan baku produksi, proses pengolahan, marketing, promosi, hingga produk siap konsumsi harus sesuai dengan standar halal. Secara umum ada empat aktivitas utama dalam halal supply chain, yaitu: (1) Halal procurement, (2) halal manufacturing, (3) halal distribution, (4) halal logistic ${ }^{24}$.

1. Halal Procurement (Pengadaan)

Pengadaan produk halal yaitu proses pengadaan bahan baku halal terdiri dari keterlibatan dalam kegiatan yang berfokus untuk menjaga integritas halal sepanjang rantai pasokan. Penilaian bahan baku halal tidak hanya dari produknya yang halal, melainkan sumber dan sistem pembayarannya juga.

2. Halal Manufacturing (Pengolahan)

Proses pengolahan halal yaitu proses transformasi bahan baku menjadi produk dengan prosedur sesuai dengan standard halal. Proses pengolahan menjadi fase yang memiliki tingkat risiko penyebab ketidakhalalan tinggi. Sebabnya perlu adanya penerapan sistem syariah internal perusahaan.

3. Halal Distribution (Distribusi)

Distribusi halal meliputi pengemasan dan wadah produk halal. Karaktersitik utama dalam pengemasan produk yang halal yaitu bahan pengemasan harus halal dan baik. Salah satu permasalahan yang diangkat dalam kemasan halal adalah sertifikasi pada kemasan tersebut ${ }^{25}$.

4. Halal Logistic (Rantai pasokan)

Logistik mencakup pengorganisasian, perlindungan, dan identifikasi produk dan bahan sebelum sampai kepada konsumen ${ }^{26}$. Status halal tidak hanya mempertimbangkan zat

17 Rony Dayan, Peter Heisig, and Florinda Matos, "Knowledge Management as a Factor for the Formulation and Implementation of Organization Strategy," Journal of Knowledge Management 21, no. 2 (2017): 308-29.

18 Harri Laihonen, Antti Lönnqvist, and Juha Metsälä, "Two Knowledge Perspectives to Growth Management," Vine 45, no. 4 (2015): 473-94.

19 Soojin Kim, "Strategic Predisposition in Communication Management: Understanding Organizational Propensity towards Bridging Strategy," Journal of Communication Management 20, no. 3 (2016): 23254.

${ }^{20}$ Mohd Imran Khan, Abid Haleem, and Shahbaz Khan, "Defining Halal Supply Chain Management," Supply Chain Forum 19, no. 2 (2018): 122-31.

21 A.Z. Aghwanad; A. U. Bello; A. A. Abubakar; J. C. Imlan; A. Q. Sazili, "Efficient Halal Bleeding, Animal Handling, and Welfare: A Holistic Approach for Meat Quality," Meat Science 1, no. 21 (2016).

22 Ahmad Yunadi, "Pasar Islami Perspektif Santri (Studi Pondok Pesantren Krapyak Yogyakarta)," JURNAL LITERASI 2, no. 1 (2009): 1-28.

23 A N Y Meilani, "Persepsi Santri Terhadap Bank Syariah," JEBI (Jurnal Ekonomi Dan Bisnis Islam) 2, no. 2 (2017): 1-14.

24 M. Tieman; van der Vorst; M. Che Ghazali, "Principles in Halal Supply Chain Management."

25 M. Johan M. Thalib, "Isu Dalam Kemasan Halal," Jurnal Bisnis Internasional Dan Manajemen 5, no. 5 (2012): 94-98.

26 Emi Normalina Omar, Harlina Suzana Jaafar, and Muhamad Rahimi Osman, "Assessing HalalanToyyiban Food Supply Chain in the Poultry Industry," International Halal Conference 2012 (INHAC) 00, no. 2011 (2012): 4-5. 
produknya saja, melainkan proses distribusi dan marketing juga termasuk dalam rantai pasok produk halal. Prinsip-prinsip halal supply chain sebagaimana Gambar 4.2 berikut.

Gambar 3.

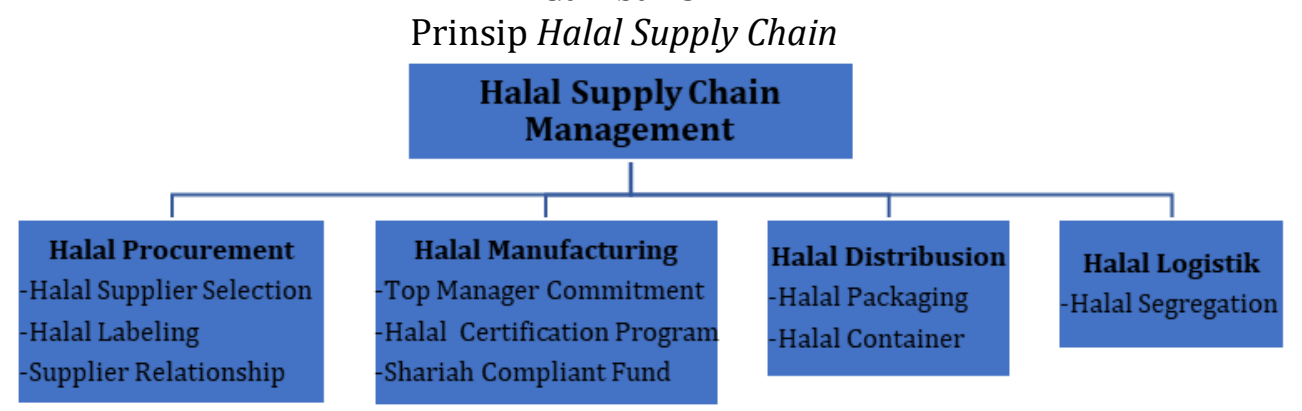

Sumber: Tieman, Vorst, dan Ghazali27

\section{B. Ekosistem Pesantren Mewujudkan Manajemen Halal Supply Chain}

Pesantren sebagai bagian integral masyarakat mempunyai tanggung jawab untuk mengembangkan dan memberdayakan masyarakat dalam berbagai bidang, termasuk bidang ekonomi. Hal ini, tentu merupakan tantangan bagi pesantren yang selama ini berkutat dalam bidang ilmu-ilmu keagamaan ${ }^{28}$. Pesantren memiliki basis sosial yang jelas, karena keberadaannya menyatu dengan masyarakat. Pesantren dapat berperan mencetak tenagatenaga terampil dan berkarakter serta memberi manfaat pada lingkungan sekitar ${ }^{29}$.

Berbagai ekosistem pesantren tersebut tentu menegaskan bahwa pesantren potensial berperan sebagai penggerak bagi peningkatan kesejahteraan masyarakat ${ }^{30}$. Artinya, pesantren berpotensi kuat sebagai motor penggerak dalam pemberdayaan ekonomi umat ${ }^{31}$. Berbagai keunggulan pesantren inilah yang menegaskan bahwa ekosistem industri halal di pesantren sangat strategis diterapkapkan manajemen halal supply chain. Apalagi, berbagai pemenuhan kebutuhan industri halal dewasa ini terbilang kompleks, menjadikan manajemen halal supply chain sangatlah penting.

Disain manajemen halal supply chain di pesantren, implementasinya harus terus menerus dengan kerangka kerja yang lengkap dan berkelanjutan. Mengingat, kerangka kerja ini dapat memastikan penyelesaian pada masalah yang berkaitan dengan biaya sistem, pemeliharaan, dan juga optimalisasi sumber daya lainnya. Selain itu, penerapan terbaik praktik bisa menjadi parameter penting sistem keberhasilan. Kemudian, masalah yang tidak diinginkan berkaitan dengan sistem operasional bisnis halal dapat diselesaikan dengan mengintegrasikan informasi antara pemasok dan pembeli dalam sistem bisnis terintegrasi dengan teknologi. Hal ini diharapkan dapat mengoptimalkan manajemen halal supply chain dengan biaya yang efektif dan efisien ${ }^{32}$.

\footnotetext{
${ }^{27}$ M. Tieman; van der Vorst; M. Che Ghazali, "Principles in Halal Supply Chain Management.”

28 A. Zaenurrossyid; Ahmad Nuruddin, "Modal Sosial Pesantren Jawa Pesisiran Utara Dalam Pemberdayaan Masyarakat," Islamic Review: Jurnal Riset Dan Kajian Keislaman VIII, no. 1 (2019): 1-16. ${ }^{29}$ M Sofyan Alnashr and Muhammad Labib, "Spiritual Entrepreneurship di Pesantren Entrepreneur AlMawaddah Kudus," Islamic Review: Jurnal Riset Dan Kajian Keislaman VIII, no. 1 (2019): 63-85.

30 Imam Nurhadi; Hari Subiantoro; Nafik Ummurul Hadi, "Pemberdayaan Masyarakat Pondok Pesantren untuk Meningkatkan Minat Masyarakat: Studi Kasus Pemberdayaan Santri Pondok Pesantren Nurul Ulum Munjungan," Al-Idarah: Jurnal Kependidikan Islam VIII, no. 1 (2018): 142-53.

${ }^{31}$ R Lukman Fauroni, "Model Pemberdayaan Ekonomi Ala Pesantren," INFERENSI: Jurnal Penelitian Sosial Keagamaan 5, no. 1 (2011): 1-17.

${ }^{32}$ Wan Azlan Wan Hassan et al., "The Perception on Halal Supply Chain Management Systems Implementation of SMEs in Selangor," Indian Journal of Science and Technology 9, no. 34 (2016): 1-8.
} 
Manajemen halal supply chain ini tentu akan lebih efektif dan efisien jika ditunjang dengan integrated digital system guna mempermudah implementasinya. Integrated digital system ini menggunakan prinsip efektif dan effesiensi memakai integrasi kawasan industri halal di lingkungan pesantren berbasis teknologi digital sehingga mampu menekan biaya serta memaksimalkan output dan income. Konsep manajemen halal supply chain yang dipadukan dengan integrated digital system di lingkungan pesantren menjadi seperti kawasan industri halal dimana pengadaan bahan, pengolahan produk, distribusi, dan marketing berada dalam satu kawasan yang distandarisasi kehalalalnya. Dengan kata lain, pesantren juga perlu memahami literasi digital sebagai bagian dari modernisasi ${ }^{33}$.

Kawasan industri halal di lingkungan pesantren dengan paduan integrated digital system dan manajemen halal supply chain disebut sebagai Integrated Halal Zone (IHZ). Kawasan IHZ ini akan mendorong industri halal cepat berkembang. Selain itu, pihak pesantren bekerja sama dengan MUI akan dapat dengan mudah mengawasi standar kehalalan produk dari hulu hingga hilir. Proses kontroling, pengawasan, dan evaluasi dapat dilakukan dengan cepat dan tidak memakan biaya yang besar. Sudah saatnya industri halal Indonesia berbasis pesantren untuk bangkit dan mampu bersaing dengan negara-negara industri halal terbaik dunia.

\section{Tantangan Manajemen Halal Supply Chain}

Manajemen halal supply chain belum banyak diterapkan di Indonesia, termasuk di pesantren. Kalaupun ada sifatnya masih sangat sporadis, kurang terkoordinasi, tidak institusional dan belum disertai dengan visi dan misi yang jelas, serta perangkat pendukungnya. Peran ini tentu tidak mudah bagi pesantren yang selama ini lebih konsentrasi bidang keagamaan dan sosial masyarakat. Apalagi, penelitian tentang ini juga masih sedikit 34 . Tentu ini adalah tantangan yang harus dihadapi pesantren, untuk merubah pola dakwah "bil lisan" menjadi "bil hal" di tengah-tengah masyarakat yang komplek ${ }^{35}$.

Madani Society 5.0 dalam konteks Islam di Indonesia hanya bisa terwujud apabila dalam masyarakat terdapat kesadaran atas hak-hak individu, kemandirian relatif dari negara, kebebasan berpendapat dan mencipta, kesederajatan di hadapan hukum, dan ketulusan dalam bakti sosial. Pesantren dapat turut berperan dalam menyemaikan nilai-nilai Madani Society 5.0 dan menyediakan pijakan-pijakan normatif berdasarkan ajaran Islam ${ }^{36}$. Selanjutnya, yang tidak kalah penting bagaimana pesantren menjadi center halal supply chain, khususnya dalam pemberdayaan ekonomi melalui industri halal yang manajemennya terintegrasi. Oleh karennya, beberapa tantangan berkaitan manajemen halal supply chain harus mendapat perhatian serius diantaranya sebagai berikut.

1. Memastikan Pelaksanaan Regulasi Produk Halal

Sebagaimana Undang-undang Jaminan Produk Halal (UU JPH) yang telah ditetapkan pada 2014, penerapan regulasi industri halal di Indonesia semakin kompleks. Berbagai kebijakan baru dibuat dengan tujuan untuk memaksimalkan jaminan produk halal di Indonesia. Pemerintah dengan i'tikad baiknya telah menunjukkan usahanya. Tetapi, sampai saat ini implementasi regulasi tersebut masih belumlah tampak di lapangan. Oleh karena itu, sudah saatnya pesantren di Indonesia dilibatkan baik dalam perumusan maupun pelaksanannya.

33 Ali Ja'far, "Literasi Digital Pesantren: Perubahan dan Kontestasi," Islamic Review: Jurnal Riset Dan Kajian Keislaman VIII, no. 1 (2019): 17-35.

${ }^{34}$ Qurtubi and Elisa Kusrini, "Research in Halal Logistics and Halal Supply Chain: Issue and Area Development," in MATEC Web of Conferences, vol. 154, 2018, 2-5.

35 Nadzir, "Membangun Pemberdayaan Ekonomi di Pesantren."

36 Wahyuddin Halim, "Peran Pesantren dalam Wacana dan Pemberdayaan Masyarakat Madani," AKADEMIKA: Jurnal Pemikiran Islam 22, no. 2 (2017): 191. 
Dikarenakan seluruh proses sertifikasi bermuara pada BPJH, maka menjadi tantangan bagi lembaga tersebut untuk menyusun sistem sertifikasi yang efektif, kredibel, efisien, dan akuntabel. Harapannya dapat menjawab seluruh tuntutan dan kebutuhan masyarakatnya (Faidah, 2017). Penetapan standar halal oleh Badan Standardisasi Nasional (BSN) bersama BPJPH harus mampu mengesampingkan sentimen setiap daerah. Hal ini dikarenakan adanya kantor-kantor LPH diberbagai daerah nanti cenderung menampilkan perbedaan yang mencerminkan keragamaan pada masing-masing daerah. Proses ini juga sudah saatnya melibatkan pesantren.

2. Meningkatkan Jaminan Produk Halal dengan Teknologi

Dewasa ini perkembangan teknologi tidak bisa dipungkuri. Berbagai device baru diciptakan dalam rangka memudahkan urusan manusia, termasuk teknologi guna menjamin kehalalan produk dan kepercayaan konsumen ${ }^{37}$. Pesantren tentunya harus menggandeng lembaga seperti LPPOM MUI, LIPI, dan BPPT guna menjawab kompleksitas tantangan ini yang merupakan tantangan bersama.

Satu contoh kasus, hingga saat ini alat pendeteksi halal-haram masih sebatas deteksi DNA daging babi. Diantaranya yaitu Polymerase Chain Reaction (PCR) yang merupakan salah satu metode akurat untuk mendeteksi cemaran daging babi. Namun, seperti yang telah diketahui bahwa bahan haram tidak hanya berasal dari babi saja. Faktor lain, seperti makanan yang mengandung darah hewan, bangkai dan sejenisnya juga sangat rentan mengkontaminasi kehalalan produk.

Oleh karena itu, berbagai pelaku industri halal, termasuk di lingkungan pesantren harus mengupayakan jaminan halal secara menyeluruh dengan adanya perkembangan teknologi yang sangat pesat saat ini. Dibutuhkan alat pendeteksi akurat, ramah lingkungan, dan juga tidak membutuhkan waktu lama. Sekali lagi, tentunya perlu bekerja sama dengan lembaga lain seperti MUI, LIPI, dan BPPT. Harapannya, kualitas produk Indonesia dapat benar-benar terjamin kehalalannya, memiliki daya saing global, dan mampu diterima oleh pasar internasional.

3. Memastikan Kehalalan Supply Chain Produk Industri

Kompleksitas proses dalam industri halal menjadi hal yang sangat penting diperhatikan aspek kehalalannya. Selama ini, perhatian konsumen pada kehalalan produk hanya sebatas pada labelisasi halal saja. Sementara, jaminan kehalalan suatu produk sebenarnya mencakup semua elemen di dalam proses pembuatan produk tersebut hingga sampai ke tangan konsumen. Secara sederhana, sistem logistik dan supply chain produk halal sebenarnya meliputi proses bahan baku dari pemasok, produksi, distribusi, dan peredaran produk di masyarakat.

Indonesia hingga saat ini, masih fokus pada proses produksi yang meliputi lokasi serta alat dan bahan baku (UU JPH). Belum adanya peraturan dan regulasi tentang logistik dan supply chain produk halal menjadi tantangan bagi Indonesia kedepannya. Diharapkan, keseluruhan proses suatu produk yakni proses logistik dan supply chain dapat menjadi perhatian pemerintah untuk mengembangkan industri halal. Harapannya, kepercayaan masyarakat berkaitan jaminan halal dapat meningkat dan produk halal kompetitif 38 .

Faktor-faktor yang mempengaruhi kerentanan halal supply chain serperti karakteristik produk dan pasar; proses bisnis, kontrol logistik, serta sumber dan jaringan

\footnotetext{
${ }^{77}$ Norasekin Ab Rashid and Jamil Bojei, "The Relationship between Halal Traceability System Adoption and Environmental Factors on Halal Food Supply Chain Integrity in Malaysia," Journal of Islamic Marketing 11, no. 1 (2019): 117-42.

${ }^{38}$ Shahbaz Khan et al., "Implementing Traceability Systems in Specific Supply Chain Management (SCM) through Critical Success Factors (CSFs)," Sustainability (Switzerland) 10, no. 1 (2018): 1-26.
} 
yang harus diperhatikan. Mengingat ini sangatlah rentan terkontaminasi ${ }^{39}$. Maka dari itu, perlu mitigasi terhadap berbagai resiko tersebut ${ }^{40}$.

Sementara itu, kasus lain pada industri ternak halal, kebijakan keamanan pangan dan kesejahteraan hewan dalam pakan ternak harus terjamin kehalalannya guna memastikan kualitas makanannya ${ }^{41}$. Keterlacakan makanan juga penting guna melacak tahapan rantai pasokan dan memastikan kualitas hewan yang dihasilkan ${ }^{42}$.

4. Pendanaan Syari'ah bagi Pengembangan Industri Pangan Halal

Permodalan bagi para pelaku industri halal juga sangat penting di dalam perkembangan sektor tersebut, terutama pada UMKM. Tantangan bagi Indonesia untuk menciptakan iklim investasi syariah yang sehat dan mampu menunjang kebutuhan industri halal. Pemerintah harus merumuskan sejumlah kebijakan agar para investor baik asing maupun lokal melakukan invesatasi syariah. Investasi tersebut bisa dialokasikan untuk mempermudah proses sertifikasi halal bagi para pelaku UMKM. Kemudahan tersebut dapat dalam bentuk biaya sertifikasi murah serta kemudahan saat pemprosesan. Hal ini dapat juga melibatkan pesantren.

Di sisi lain, kontribusi perbankan syari'ah di Indonesia juga diharapkan mampu meningkatkan perkembangan industri halal. Perbankan syariah memiliki peranan strategis dalam meningkatkan usaha UMKM terutama dalam masalah pendanaan (funding) dan supporting pada masalah pendampingan teknis dan non-teknis. Meskipun secara kualitatif perbankan syariah sudah melakukan berbagai strategi, akan tetapi secara kuantitatif ternyata peran perbankan syariah terhadap UMKM masih belum memuaskan. Hal ini tentunya patut menjadi referensi bagi pesantren dalam pendanaan industri halal dengan bermitra bank syariah ${ }^{43}$, guna optimalisasi terlaksananya manajemen halal supply chain. Berbagai tantangan tentunya penting menjadi referensi bagi pesantren dewasa ini.

D. Ekosistem Pesantren 4.0 dan Manajemen Halal Supply Chain

Era Revolusi Industri 4.0 menuntut pesantren harus selalu optimis, karena selama ini pesantren secara konsisten terbukti mampu membentengi diri terhadap derasnya budaya asing yang masuk ke Indonesia ${ }^{44}$. Dengan kata lain, pesantren harus mampu beradaptasi menjadi Pesantren 4.0 guna mewujudkan Madani Society 5.0. Demikian juga dalam implementasi manajemen halal supply chain, Pesantren 4.0 harus terlibat aktif di dalam seluruh rangkaian prosesnya.

Adapun tujuan peran Pesantren 4.0 dalam manajemen halal supply chain yaitu mengembangkan rantai nilai halal melalui pesantren untuk berbagai industri halal; mengembangkan perekonomian piramida bawah dengan prinsip syariah (adil, transparan, dapat diacak, akuntabel, dan aman); dan untuk mendukung peran bank sentral dalam memantau bagian piramida bawah di Indonesia.

Dalam rangka tercapaianya tujuan implementasi halal supply chain tersebut, tentu harus dipersiapkan seluruh prasyaratnya seperti ketersediaan santri untuk bergabung

\footnotetext{
39 Ujang Maman, Akhmad Mahbubi, and Ferry Jie, "Halal Risk Mitigation in the Australian-Indonesian Red Meat Supply Chain," Journal of Islamic Marketing 9, no. 1 (2018): 60-79.

${ }^{40}$ Shahbaz Khan et al., "Prioritising the Risks in Halal Food Supply Chain: An MCDM Approach," Journal of Islamic Marketing, 2019.

${ }^{41}$ Arif Julianto Sri Nugroho, Roos Kities Andadari, and Eric Kunto Aribowo, "Supply Chain and Purchasing Behavior of Halal Chicken Meat," Share: Jurnal Ekonomi Dan Keuangan Islam 7, no. 2 (2018): 162-79.

42 Emi Normalina Omar and Harlina Suzana Jaafar, "Halal Supply Chain in the Food Industry - A Conceptual Model," ISBEIA 2011 - 2011 IEEE Symposium on Business, Engineering and Industrial Applications, no. September (2011): 384-89.

${ }^{43}$ Meilani, "Persepsi Santri Terhadap Bank Syariah."

${ }^{44}$ RZ. Ricky Satria Wiranata, "Tantangan, Prospek dan Peran Pesantren dalam Pendidikan Karakter di Era Revolusi Industri 4.0," Jurnal Komunikasi dan Pendidikan Islam 8, no. 1 (2019): 61-92.
} 
dengan program ini; ketersediaan dan keterbuakaan masyarakat sekitar untuk bergabung dengan program; kesiapan sistem implementasi yang terintegrasi dengan permodalan dan market; jumlah lahan minimal yang tersedia; dan biaya awal untuk melakukan assessement, pelatihan, dan pendampingan; meningkatkan kepercayaan jaminan halal produk industri. Karenanya, diperlukan suatu kerangka kerja Pesantren 4.0 dalam mengembangkan manajemen halal supply chain.

Gambar 4.

Kerangka Pesantren 4.0 dalam Halal Supply Chain

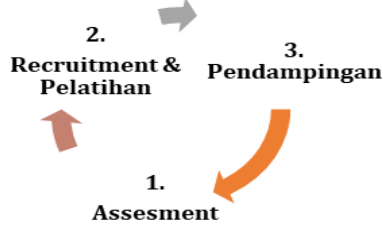

PESANTREN 4.0 MUI LIPI BPPT PENDANAAN SYARIAH

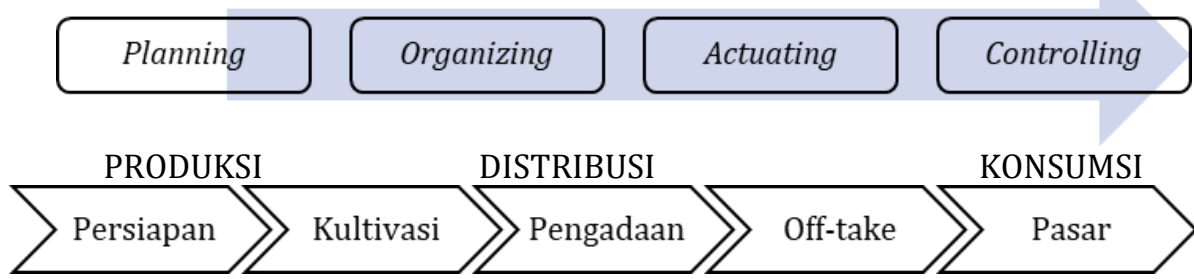

Dengan adanya peran aktif Pesantren 4.0 dalam aspek manajemen halal supply chain diharapkan dapat meningkatnya kepercayaan masyarakat terhadap jaminan kehalalan suatu produk industri45. Kesejahteraaan masyarakat di lingkungan pesantren; juga meningkat. Demikian juga dampak sosial serta ekonomi dapat dirasakan oleh entitas di pesantren serta masyarakat lingkungan sekitarnya. Adapun, platform halal value chain sebagai mana gambar berikut.

Gambar 5.

Halal Value Chain Platform

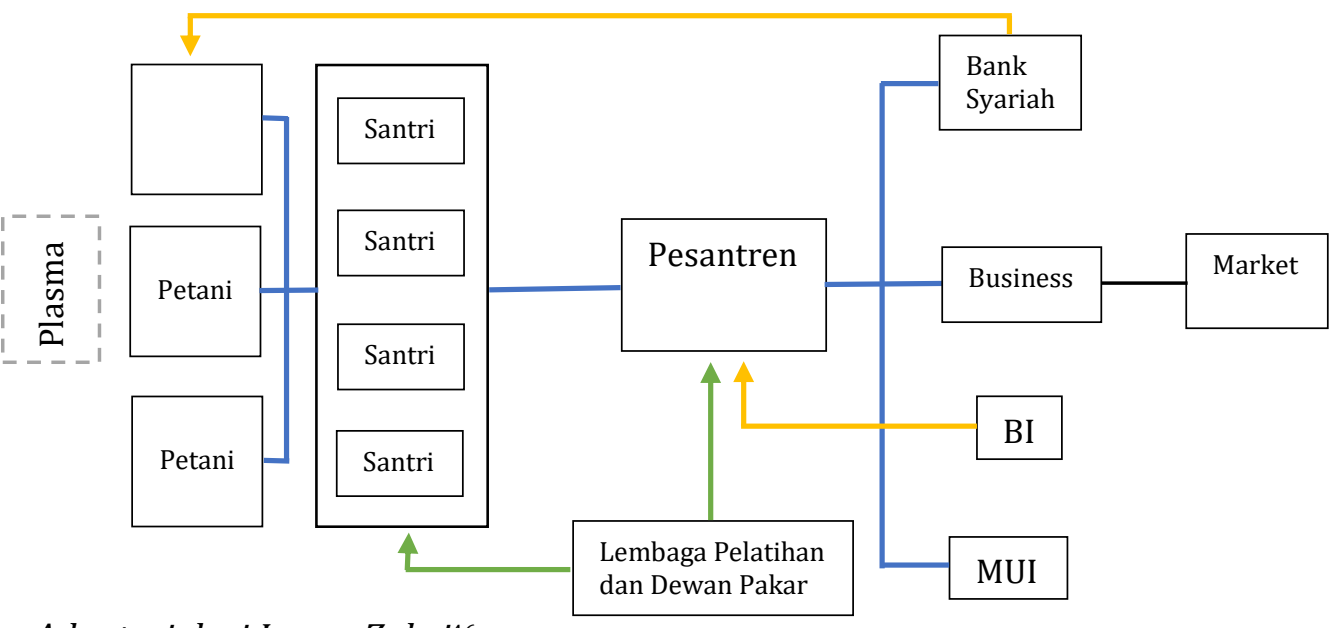

Sumber: Adaptasi dari Imron Zuhri ${ }^{46}$

45 Fadhlur Rahim Azmi et al., "Perception of Food Manufacturers towards Adoption of Halal Food Supply Chain in Malaysia: Exploratory Factor Analysis," Journal of Islamic Marketing 11, no. 3 (2019): 571-89, https://doi.org/10.1108/JIMA-12-2018-0236.

${ }^{46}$ Imron Zuhri, "Pemanfaatan Teknologi Blockchain Dalam Pemberdayaan Ekonomi Pesantren," in ISEF, 2019. 
Ekosistem Pesantren 4.0 dalam implementasi manajemen halal supply chain tentunya membutuhkan dukungan pemerintah. Dukungan pemerintah diperlukan untuk memberikan pelatihan terhadap sumber daya manusia; mempromosikan layanan halal supply chain; mempercepat pertumbuhan industri halal dengan mengembangkan infrastruktur logistic; dan pengembangan halal supply chain melalui kebijakan dan regulasi yang diputuskan. Selain dukungan pemerintah, manajemen halal supply chain juga harus perencanaan transportasi, manajemen teknologi informasi, manajemen sumber daya manusia; hubungan kolaboratif, sertifikasi halal, dan ketelusuran informasi halal ${ }^{47}$. Dengan itu implementasi manajemen halal supply chain melalui ekosistem pesantren, harapannya Madani Society 5.0, khususnya bidang ekonomi dapat terwujud.

\section{PENUTUP}

Berdasarkan uraian pembahasan, dapat disimpulkan diantaranya Pertama, secara umum empat prinsip halal supply chain, yaitu halal procurement (pengadaan), halal manufacturing (pengolahan), halal distribution (distribusi), dan halal logistic (rantai pasokan), Kedua, ekosistem Pesantren dalam implementasi manajemen halal supply chain tentunya membutuhkan dukungan pemerintah, perencanaan transportasi, manajemen teknologi informasi, manajemen sumber daya manusia; hubungan kolaboratif, sertifikasi halal, dan ketelusuran informasi halal, Ketiga, tantangan pesantren dalam penerapan manajemen halal supply chain diantaranya memastikan pelaksanaan regulasi dan kebijakan produk halal; meningkatkan jaminan produk halal dengan teknologi; memastikan kehalalan supply chain produk industri; serta pendanaan syari'ah bagi pengembangan industri pangan halal. Berdasarkan kesimpulan tersebut, implementasi dari halal supply chain di lingkungan pesantren patut menjadi solusi strategis dalam menyelesaikan masalah berkaitan dengan halal supply chain. Apalagi, mengingat ekosistem pesantren sangat lekat dengan nilai-nilai syariat Islam. Oleh karenanya, disain manajemen halal supply chain patut dimanajemen secara terintegrasi.

\section{DAFTAR PUSTAKA}

A.Z. Aghwanad; A. U. Bello; A. A. Abubakar; J. C. Imlan; A. Q. Sazili. "Efficient Halal Bleeding, Animal Handling, and Welfare: A Holistic Approach for Meat Quality." Meat Science 1, no. 21 (2016). https://doi.org/https://doi.org/10.1016/j.meatsci.2016.06.028.

Ab Rashid, Norasekin, and Jamil Bojei. "The Relationship between Halal Traceability System Adoption and Environmental Factors on Halal Food Supply Chain Integrity in Malaysia." Journal of Islamic Marketing 11, no. 1 (2019).

Abdullah, M. Amin. Islamic Studies di Perguruan Tinggi: Pendekatan Integratif-Interkonektif. Yogyakarta: Pustaka Pelajar, 2006.

Adinugraha, Hendri Hermawan, and Mila Sartika. "Halal Lifestyle Di Indonesia." An-Nisbah: Jurnal Ekonomi Syariah 5, no. 2 (2019). https://doi.org/10.21274/an.2019.5.2.layout.

Alnashr, M Sofyan, and M. Labib. "Spiritual Entrepreneurship Di Pesantren Entrepreneur AlMawaddah Kudus." Islamic Review: Jurnal Riset Dan Kajian Keislaman VIII, no. 1 (2019).

Azlan Wan Hassan, Wan, Raja Mohd Tariqi Raja Lope Ahmad, Azhar Hamid, and Norziha Megat Mohd Zainuddin. "The Perception on Halal Supply Chain Management Systems Implementation of SMEs in Selangor." Indian Journal of Science and Technology 9, no. 34 (2016). https://doi.org/10.17485/ijst/2016/v9i34/100843.

Azmi, Fadhlur Rahim, Abu Abdullah, Haslinda Musa, and Wan Hasrulnizzam Wan Mahmood. "Perception of Food Manufacturers towards Adoption of Halal Food Supply Chain in

${ }^{47}$ Mohamed Syazwan et al., "Halal Supply Chain Critical Success Factors : A Literature Review," 2014, 44-71. 
Malaysia: Exploratory Factor Analysis." Journal of Islamic Marketing 11, no. 3 (2019). https://doi.org/10.1108/JIMA-12-2018-0236.

Dayan, Rony, Peter Heisig, and Florinda Matos. "Knowledge Management as a Factor for the Formulation and Implementation of Organization Strategy." Journal of Knowledge Management 21, no. 2 (2017). https://doi.org/10.1108/JKM-02-2016-0068.

Djakfar, Muhammad. Pariwisata Halal Perspektif Multidimensi: Peta Jalan Menuju Pengembangan Akademik \& Industri Halal Di Indonesia. Malang: UIN-Maliki Press, 2017.

Fahhan, Achmad Muchaddam. "Sanitasi dan Dampaknya Bagi Kesehatan: Studi dari Pesantren." Jurnal Masalah-Masalah Sosial 10, no. 1 (2019). https://doi.org/https://doi.org/10.22212/aspirasi.v7i1.1084 link.

Fauroni, R Lukman. "Model Pemberdayaan Ekonomi Ala Pesantren." INFERENSI: Jurnal Penelitian Sosial Keagamaan 5, no. 1 (2011).

Hadi, Imam Nurhadi; Hari Subiantoro; Nafik Ummurul. "Pemberdayaan Masyarakat Pondok Pesantren untuk Meningkatkan Minat Masyarakat: Studi Kasus Pemberdayaan Santri Pondok Pesantren Nurul Ulum Munjungan." Al-Idarah: Jurnal Kependidikan Islam VIII, no. 1 (2018). https://doi.org/http://dx.doi.org/10.24042/alidarah.v8i1.2916.

Halim, Wahyuddin. "Peran Pesantren dalam Wacana dan Pemberdayaan Masyarakat Madani." AKADEMIKA: Jurnal Pemikiran Islam 22, no. 2 (2017). https://doi.org/10.32332/akademika.v22i2.976.

Haryono, Haryono, and Dwi Iryaning Handayani. "Pemodelan Sistem Traceability Halal Supply Chain dalam Menjaga Integritas Produk Makanan Halal dengan Pendekatan Interpretive Structural Modeling (ISM)." Jurnal PROZIMA (Productivity, Optimization and Manufacturing System Engineering) 2, no. 2 (2018). https://doi.org/10.21070/prozima.v2i2.2196.

Ja'far, Ali. “Literasi Digital Pesantren: Perubahan Dan Kontestasi." Islamic Review: Jurnal Riset Dan Kajian Keislaman VIII, no. 1 (2019).

Julianto Sri Nugroho, Arif, Roos Kities Andadari, and Eric Kunto Aribowo. "Supply Chain and Purchasing Behavior of Halal Chicken Meat." Share: Jurnal Ekonomi Dan Keuangan Islam 7, no. 2 (2018). https://doi.org/10.22373/share.v7i2.3493.

Khan, Mohd Imran, Abid Haleem, and Shahbaz Khan. "Defining Halal Supply Chain Management." Supply Chain Forum 19, no. 2 (2018). https://doi.org/10.1080/16258312.2018.1476776.

Khan, Shahbaz, Abid Haleem, Mohd Imran Khan, Mustufa Haider Abidi, and Abdulrahman AlAhmari. "Implementing Traceability Systems in Specific Supply Chain Management (SCM) through Critical Success Factors (CSFs)." Sustainability (Switzerland) 10, no. 1 (2018). https://doi.org/10.3390/su10010204.

Khan, Shahbaz, Mohd Imran Khan, Abid Haleem, and Abdur Rahman Jami. "Prioritising the Risks in Halal Food Supply Chain: An MCDM Approach." Journal of Islamic Marketing, 2019. https://doi.org/10.1108/JIMA-10-2018-0206.

Kim, Soojin. "Strategic Predisposition in Communication Management: Understanding Organizational Propensity towards Bridging Strategy." Journal of Communication Management 20, no. 3 (2016). https://doi.org/10.1108/JCOM-06-2015-0050.

Laihonen, Harri, A. Lönnqvist, and Juha Metsälä. "Two Knowledge Perspectives to Growth Management." Vine 45, no. 4 (2015). https://doi.org/10.1108/VINE-11-2014-0063.

M. Thalib, M. Johan. "Isu dalam Kemasan Halal." Jurnal Bisnis Internasional dan Manajemen 5, no. 5 (2012).

M. Tieman; van der Vorst; M. Che Ghazali. "Principles in Halal Supply Chain Management."

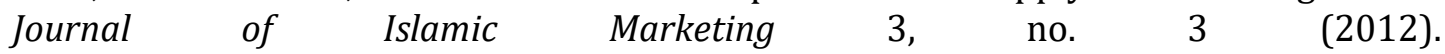


https://doi.org/https://doi.org/10.1108/17590831211259727.

Maman, Ujang, Akhmad Mahbubi, and Ferry Jie. "Halal Risk Mitigation in the AustralianIndonesian Red Meat Supply Chain." Journal of Islamic Marketing 9, no. 1 (2018). https://doi.org/10.1108/JIMA-12-2015-0095.

Meilani, “Persepsi Santri Terhadap Bank Syariah.” Jurnal Ekonomi Bisnis Islam 2, no. 2 (2017).

Nadzir, Mohammad. "Membangun Pemberdayaan Ekonomi di Pesantren." Economica: Jurnal Ekonomi Islam 6, no. 1 (2015). https://doi.org/10.21580/economica.2015.6.1.785.

Nuruddin, A. Zaenurrossyid; Ahmad. "Modal Sosial Pesantren Jawa Pesisiran Utara dalam Pemberdayaan Masyarakat." Jurnal Riset dan Kajian Keislaman VIII, no. 1 (2019).

Omar, Emi Normalina, and Harlina Suzana Jaafar. "Halal Supply Chain in the Food Industry - A Conceptual Model." ISBEIA 2011 - 2011 IEEE Symposium on Business, Engineering and Industrial Applications, (2011). https://doi.org/10.1109/ISBEIA.2011.6088842.

Omar, Emi Normalina, Harlina Suzana Jaafar, and Muhamad Rahimi Osman. "Assessing Halalan-Toyyiban Food Supply Chain in the Poultry Industry." International Halal Conference 2012 (INHAC) 00, no. 2011 (2012).

Qurtubi, and Elisa Kusrini. "Research in Halal Logistics and Halal Supply Chain: Issue and Area Development." In MATEC Web of Conferences, 154:2-5, 2018. https://doi.org/10.1051/matecconf/201815401096.

Riaz, Mian N, and M. Chaudry. Halal Food Production. New York: CRC Press LLC, 2004.

Saifudin, Adam Mohd, Siti Norezam Othman, and Ezanee Mohamed Elias. "Exploring in Setting a Model for Islamic Supply Chain in Malaysia" 7, no. 1 (2017).

Santos, Fernando C.A. "Integration of Human Resource Management and Competitive Priorities of Manufacturing Strategy." International Journal of Operations and $\begin{array}{lllll}\text { Production Management } & \text { 20, } & \text { no. } & 5 & \text { (2000). }\end{array}$ https://doi.org/10.1108/01443570010318986.

Sariati, Ning Purnama, and Binti Mutafarida. "Pesantren Dan Konsumsi Halal Santri (Studi Kasus Di Pesantren Syarif Hidayatulah Rejomulyo Kediri),” 2:193-212, 2019.

Soon, Jan Mei, M. Chandia, and J. M. Regenstein. "Halal Integrity in the Food Supply Chain." British Food Journal 119, no. 1 (2017). https://doi.org/10.1108/BFJ-04-2016-0150.

Sutopo, Nailil Muna; Wahyudi. "Perkembangan Penelitian Halal Food Supply Chai: Studi Kasus Database Scopus." In Prosiding SNST Ke-9 Tahun 2018. Fakultas Teknik Universitas Wahid Hasyim, 2018.

Syazwan, Mohamed, Ab Talib, A. Bakar, and A. Hamid. "Halal Supply Chain Critical Success Factors : A Literature Review," 2014. https://doi.org/10.1108/JIMA-07-2013-0049.

Thomson Reuters. "State of The Global Islamic Economy Report 2016-2017." Dubai, 2016.

United Nations. “The Sustainable Development Goals Report.” New, 2019.

Waharini, Faqiatul Mariya, and Anissa Hakim Purwantini. "Model Pengembangan Industri Halal Food di Indonesia." Jurnal Muqtasid 9, no. 1 (2018).

Wiranata, RZ. R. Satria. "Tantangan, Prospek dan Peran Pesantren dalam Pendidikan Karakter di Era Revolusi Industri 4.0." Jurnal Komunikasi Dan Pendidikan Islam 8, no. 1 (2019).

Yunadi, Ahmad. "Pasar Islami Perspektif Santri (Studi Pondok Pesantren Krapyak Yogyakarta)." JURNAL LITERASI 2, no. 1 (2009).

Zuhri, Imron. "Pemanfaatan Teknologi Blockchain dalam Pemberdayaan Ekonomi Pesantren." In ISEF, 2019. 